\title{
The rhetorics of finding a new identity in a multi-religious and multi-ethnic society: The case of the book of Chroni- cles $^{1}$
}

\author{
L C Jonker
}

(Universiteit van Stellenbosch)

\section{ABSTRACT \\ The rhetorics of finding a new identity in a multi-religious and multi-ethnic society: The case of the Chronicles.}

Scholars generally agree that the Books of Chronicles are the products of certain Israelite (Levitical) groups in the Persian province of Jehud who struggled with the dissonance between their older historical and theological traditions on the one hand, and their present reality on the other hand. Within the totally different conditions under Persian rule (a multi-religious and multi-ethnic society) they had to find a new identity. The primary focus of this article is to examine the rhetorics of the intense struggle for a new identity presented to the reader in the Books of Chronicles. It is argued that this new identity represented a shift from a historically-defined identity that lasted from the monarchical period to the early postexilic phase, to a cultic identity during the Persian era. The article also endeavours to relate the identity forming discourse of these biblical books to the present processes in post-apartheid South African society. The question is asked whether a similar shift can be observed in this modern situation.

\section{INTRODUCTION}

Religious communities exist and function within the wider context of society - society that is formed amongst other factors by sociocultural, political, economical and power relations. Because these

1 This article is an adapted version of a paper that was presented at the Annual Meeting of the Old Testament Society of Southern Africa (OTSSA) in Stellenbosch on 11 September 2002. It forms part of research that was done with the financial support of the Alexander von Humboldt Foundation, and that is published in Jonker (2003). The financial support of the Humboldt Foundation towards this research and the publication of the monograph is gratefully acknowledged here. The opinions expressed here are that of the author, and not necessarily that of the Humboldt Foundation. 
factors change over time, religious communities often have to situate themselves anew in changed circumstances. Reflection on the own identity is often quite prominent in periods of transition.

The proclamation of the post-exilic Persian province Jehud in the sixth century BC, was such a phase in the history of the Jewish religion. It was a phase of finding a new identity. This phase was characterised by two processes: (a) A process of reappropriation, in the form of exegesis of their older historical and theological traditions, as well as (b) a phase of integration by means of a new national self-understanding into a universal humanity.

The aim of this article is to explore the dynamics of such a phase of forming a new identity in ancient Israel, in order to enhance our understanding of the dynamics of our present South African situation. I will argue that the Books of Chronicles provide us with a literature that was performative in this phase. I will firstly provide a description of the socio-historical and socio-religious conditions of the time of origin (section 2). Within this context, I will subsequently show how the rhetorics of the Books of Chronicles advocate an identity based on the cult, in contrast to the historically-based identity described in the Deuteronomistic History (sections 3-4). I will then end by examining whether our study of the identity forming discourse in the Books of Chronicles can help us in our understanding of the dynamics within religious communities in present-day South Africa (section 5).

\section{BETWEEN CONTINUITY AND A NEW IDENTITY}

\subsection{The socio-historical context of the post-exilic Israelite community}

An important step in socio-historical contextualisation is to identify indications within biblical literature of its date of origin ${ }^{2}$. With regard to the Books of Chronicles, various arguments have already

2 A circular argumentation should be avoided. These indications from Chronicles should not merely be used to construct a presumed phase in history, and then subsequently, to associate Chronicles with that constructed period. The indications from Chronicles should rather be correlated with other available epigraphic and archaeological data. 
been advanced by scholars to come to various conclusions ${ }^{3}$. Japhet (1993), like the majority of the major commentators, uses the "Late Biblical Hebrew" language of Chronicles as argument to fix the upper limit of the composition of the book as no earlier than the post-exilic period, "and probably well into it". The absence of Greek-Hellenistic influence, in either language or theology, points to a lower limit for the composition of Chronicles, namely before the influx of Hellenistic influence.

The work of Willi ${ }^{4}$ represents an attempt to reconstruct this Persian/early Hellenistic phase in the history of Israel $^{5}$. The continuous development during this period is reflected in the title of his book, "Juda-Jehud-Israel". Two phases in the development during the Persian period are identified, namely that of "continuity" and "national identity". Willi maintains that the early Persian period (and therefore the early post-exilic phase) in Judah was characterised by attempts towards continuity ${ }^{6}$. According to him, archaeological finds from this period support a picture of a mainly unchanged continuation of the exilic, and even pre-exilic, conditions. In the absence of a centrally-organised administration, the continuity of the past conditions was mainly achieved within local towns and communities. Literature from the early Persian period, according to Willi, shows a strong tendency towards conservation. The past should not be forgotten, and it should be continued into the present conditions. Not only the population that remained in Palestine during the exile was responsible for this continuation of the past traditions, but also, and especially, those in the Diaspora in Babylonia. The start of the Persian period in Israel's religious history is therefore to be understood as a phase of conservation and continuity. Willi argues accordingly that the exile should not be regarded as such a radical breach in the history of Israel. The exilic period is characterised by a continuation of tradition and institutions of the past. Although the temple in Jeru-

3 Cf. e.g. Strübind (1991:23-25); Klein (1992:992-1002); Japhet (1993:2328) for summaries of the different arguments that are used in scholarship, and the different conclusions to which these arguments lead.

4 Cf. Willi (1972, 1995 and 1999).

5 Cf. also Davies (1991) and Carter (1999).

6 Cf. Deist's criticism against the so-called Persian fiction theory (2000: 64-77). 
salem did not exist any longer, their cultic practices were still oriented nationalistically - it was an attempt to recreate the past in the present.

However, between the middle and the end of the 5th century $\mathrm{BCE}$, the situation changed radically. The reason for this breach in the existence and development of post-exilic Israel, which is also witnessed by archaeological finds (e.g. the change in the Siegelkultur), is the final proclamation of an independent Persian province of Jehud. According to Willi, a radical new phase started here. During this phase it was no longer possible to continue developing their older traditions, the Pentateuch and the Deuteronomistic History. Conservation of the older traditions no longer took place by means of further development of the older traditions, but rather by means of reappropriation, exegesis and study of the older Scriptures. Between the final form of Genesis to 2 Kings on the one hand, and 1-2 Chronicles on the other hand, lies a radical new development. The proclamation of an independent Persian province Jehud introduced a phase of finding a new identity among the Jewish people within and outside Jehud. This phase was characterised by two important processes: (a) A process of reappropriation in the form of exegesis of their older historical and theological traditions, as well as (b) a phase of integration into the multi-ethnic and multi-religious Persian Empire by means of the new national self-understanding of being part of a universal humanity ${ }^{7}$.

The new phase for Jahweh's people that started with the establishment of the Persian province of Jehud was a turbulent phase of socio-political change. This socio-political change necessitated not only thorough reflection on their historical and theological traditions of the past, but also a reorientation of these traditions in order to be relevant in new socio-political circumstances. They had, for example, the task of reflecting on the position of the foreign Persian king that reigned over them. How should such a king be viewed, given their own historical Davidic traditions? And how should the relationship between this foreign king and the God of Israel be valued, given their own theocratic traditions? Willi has shown convincingly that Jahweh's people did not react to these changes in a spirit of opposition or resistance, but rather in the spirit of integration, of develo- 
ping a new identity among a diversity of nations, and of identifying a new role as part of universal humanity. The Jews saw the Persian great kings to be in continuity with their own ancient traditions, in which the foreign king is portrayed as being appointed by the God of Israel $^{8}$. However, this acknowledgement of the foreign kings as God's appointed rulers, did not prevent them from continuing to regard themselves as being the people of Israel $^{9}$.

It is precisely in this situation of forming a new identity in continuity of who they were, namely Jahweh's people, and simultaneously integrating into a wider socio-political context ${ }^{10}$, that made it absolutely necessary for them to convince others of this identity.

\subsection{The religious-historical context of the post-exilic Israelite community}

What, then, were the religious conditions during the latter half of the Persian era in the province of Jehud? How did the process of finding a new identity within a multi-ethnic and multi-cultural society impact on the religious conventions of the Jews?

In the first instance, it is important to notice that this was the time of the Second Temple. Although sacrifices and prayers continued during the time of the exile, when the Jerusalem temple was still in ruins ${ }^{11}$, these practices were in unbroken continuity with the conditions during the Kingdom of Judah before the exile, namely with the memory of a centralised and royal sanctuary. The only

\section{Willi (1995:174). \\ 9 Willi (1995:175).}

10 Willi (1999:76) accentuates that society was truly multi-ethnic and multi-cultural already during the exile: "... (sie) fanden sich in einem ohnehin schon ethnisch recht vielfältigen Babylonien wieder. Die Multiethnizität und Multikulturalität im Alten Orient ist von kaum einer Seite, auch nicht von Gen. 11, negativ gewertet worden". This multi-ethnicity and multi-culturality continued into the Persian period. During this era the difference could, according to Willi, be described as "hat[a/i]ru-Gemeinschaften" - terminology derived from the Aramaic word חטר ("Hof, Gehöft"). These communities "waren Korporationen mit gewissen eingeschränkten Befugnissen zur Selbstverwaltung vor allem in zivilrechtlichen und wohl auch religiösen Belangen und stellten eine Art Kolonie oder Landmannschaft dar" (Willi 1999:77).

11 Cf. Willi (1999:81ff.). 
people who still practised the cultic rituals were those who still regarded themselves as part of Israel.

The situation changed radically as soon as the Second Temple had been completed. The Second Temple was never seen as belonging to the religious community or the people of Israel. According to Willi, it was seen as the House of JHWH, in the truest sense of the word, God's house. This means that the significance of the Second Temple was that it was regarded as being universal, and that cultic institutions were no longer nationally oriented, but rather universally ${ }^{12}$.

The universalising tendency in the Jewish cult in the Second Temple period was probably influenced by the apparent religious tolerance $^{13}$ and openness that were prevalent in the Persian kingdom. Evidence of this tolerance can, for instance, be found in the correspondence that was discovered at Elephantine, a Jewish community in Egypt during this period. In the often-cited Passover Letter found at Elephantine (dated to $419 \mathrm{BCE})^{14}$, orders (put in the mouth of the Persian king Darius II) are given to the community to observe the Passover and Festival of Unleavened Bread ${ }^{15}$ on the dates stipulated

12 Cf. Willi (1999:82-83).

13 "Tolerance" is used here without associating it with a modern-day understanding of this concept. Donner (1986:393-394) warns: "Bei alledem ist es notwendig, Fehleinschätzungen entgegenzuwirken. ... Begriffe dieser Art wecken falsche geistesgeschichtliche Assoziationen. Es handelte sich bei den Persern selbstverständlich nicht um Toleranz im Sinne des philosophischen Relativismus oder aus Achtung vor dem Gewissen der anderen oder als soziale Tugend. Wir sind nicht im Zeitalter der europäischen Aufklärung, die diesen Begriff gross gemacht hat. Es handelte sich nicht um Toleranz aus Gesinnung, sondern aus Kalkül: aus der Einsicht, dass sich das Weltreich so würde besser und dauerhaft beherrschen lassen. .... Aber in den Fragen des geistigen und religiösen Lebens der unterworfenen Völker, ihrer Eigenart und Tradition, erwiesen sie sich eben doch als 'tolerant'. Sie versuchten nicht, regulierend und vereinheitlichend einzugreifen, sondern förderten Religion und Kultur der Untertanenvölker und griffen nicht selten sogar zum Mittel des grossköniglichen Erlasses, um den Unterworfenen die Pflege ihrer Traditionen anzubefehlen".

14 Cf. the text editions of Porten \& Yardeni (1986:54-55) as well as Porten (1996:125-126).

15 Although the words "Passover" and "Festival of Unleavened Bread" do not occur in line 3 of the letter, the dates in this line have made most 
in the Pentateuchal prescriptions ${ }^{16}$. Whatever the reason may have been for this mission to Elephantine, this text witnesses to the fact that the Jewish cult was acknowledged and respected within the Persian empire, even among the Diaspora communities ${ }^{17}$.

The scanty evidence from the Elephantine Letter also provides us with an indication that the Second Temple in Jerusalem was not the only place where the Passover was celebrated. Local sanctuaries of the Diaspora communities apparently also functioned as centres for the practising of this ritual.

\section{THE RHETORICAL STRUCTURE OF THE BOOKS OF CHRONICLES}

In this section I will attempt to show how the macro-communicative structure of the Books of Chronicles, when viewed against the background of the socio-cultural and socio-religious conditions during the Persian period in the Province Jehud (as described above), provides us with indications of how these books functioned as performative literature in the construction of a new identity. Although much more can be said about the rhetorical structure, I will focus on two rhetorical issues: (i) The deliberate combination of the Pentateuchal and Deuteronomistic traditions in the introduction to Chronicles, and (ii) the macro-structure of history according to the Chronicles in comparison to the Deuteronomistic history.

scholars reach the consensus that these would be appropriate reconstructions of the damaged parts of the line.

16 Porten (1996:125) mentions that the full intent of this significant letter still eludes us because of our ignorance as to the identity of Hananiah (mentioned in line 1) and the loss of the command from Darius to Arsames (in line 2). "Hananiah arrived from outside of Egypt, either upon the initiative of the Jewish authorities in Jerusalem or the Persian court or in response to a petition of the Elephantine Jews. If the latter, we may imagine that their observance of the dual Festivals of Passover and Unleavened Bread was being obstructed by the Egyptian priests. Hananiah succeeded in gaining the king's confirmation of their traditional rights and on his own initiative stated three of four Biblical requirements..., followed by an interlacing of Biblical requirements..., and interpretative innovations... These latter may have been recent rulings in Jerusalem" (Porter 1996:125).

17 Cf. also Donner (1986:396). 


\subsection{A universalist frame (1 Chron. 1-9 and 2 Chron. 36:22-23)}

The Deuteronomistic History, as we know, starts after the death of Moses. Although the description of history in this account relies heavily on the Pentateuchal traditions (the Exodus tradition and Deuteronomic theology in particular), it is clear that this history presents a picture of Israel from "entering the land" (Jos 1) to "losing the land" ( $2 \mathrm{Ki} 25)^{18}$. The rhetorical function of such a history, probably composed in the late-exilic period, is clear. It represents an assessment of the past in the light of the catastrophe of the exile. However, together with Willi, one may argue that this description of history does not venture into describing or advocating a new identity. It rather reflects on how the past could be continued in their present existence, given the fact that they lost the foundation stones of their national identity, namely their land, the temple and their king.

The Chronicler's history, on the other hand, is situated in a completely different framework. It starts with a mainly genealogical summary of the Pentateuchal traditions in 1 Chronicles 1-9, and it ends with the proclamation of the Persian king, Cyrus, in 2 Chronicles 36:22-23 that allowed the exiles to return to their land and to rebuild their temple in Jerusalem. A few remarks should be made about this frame:

i) The genealogical introduction starts with a repetition of names found in the Urgeschichte in Genesis 1-11. No narrative introduction is provided, and the first name to be mentioned is Adam. The first part of the long genealogical introduction clearly signifies that the history of God's people should be understood within the universal frame of humanity.

ii) It is clear that prominence is given to the Levitical lineage in the genealogical introduction. Not only does the part on the Levites occupy 81 verses in chapters 5 and 6 (according to the Hebrew verse

18 Some modern scholars (such as Konrad Schmid and Hans-Christoff Schmit) argue in favour of the existence of an Enneateuch (from Genesis to 2 Kings). Although this theory presents fresh insight into the formation of the greater composition, it does not overrule the theory that Josua to 2 Kings share a particular history of origin as smaller composition within the Enneateuch. 
count) and a few verses in chapter 9 , but it also clearly shows signs of redaction and expansion, as some commentators ${ }^{19}$ have indicated.

The last part of the genealogical introduction deals with the descendants of Saul, and the death of Saul is repeated immediately after that in chapter 10. In chapters 11-29, the history of King David is told. It therefore seems as if chapter 10 forms a bridge between the genealogical pre-history and the actual history starting with King David.

The conclusion to Chronicles (2 Chron. 36:22-23) introduces the Persian king, Cyrus, into the narrative. This reference does, of course, not occur in the Deuteronomistic History (DtrH). My opinion is that the presence of this conclusion in Chronicles (and the absence thereof in the $\mathrm{DtrH}$ ) is not merely an indication that the DtrH was composed before and the Chronicles after $538 \mathrm{BCE}$. The content of this conclusion also clearly shows that a relationship is seen between the God of Israel and the Persian king, Cyrus. The narrative even includes the following in direct speech by King Cyrus: "The Lord, the God of heaven, has given me all the kingdoms of the earth, and he has charged me to build him a house at Jerusalem, which is in Judah..." (RSV: 2 Chron. 36:23). This conclusion therefore situates not only the political history of Israel, but also its religious history in an explicit universal context. These observations will be referred to again when I summarise my argument later in this article.

\subsection{The macro-structure of history (1 Chron. 10 - 2 Chron. 36:21) presented in Chronicles}

Elsewhere $^{20}$ I have presented a detailed analysis of the text-internal context of the Chronicler's account of King Josiah's Passover. Some terminological patterns that were indicated there are also important for my present argument. Without going into the detail of the analysis, I will now provide a summary of the observations made in this regard.

The communicative structure of the Josiah narrative in 2 Chron. 34-35 provides clear indications of its pragmatic intention. The narrative aims to draw attention to the eighteenth year of King Josiah's reign as the year in which the significance of this king has become

19 Cf. Roubos (1983:96).

20 Cf. Jonker (2003a and 2003b). 
apparent. The structural and temporal organisation of the narrative supports this focus in several ways. The eighteenth year of King Josiah's reign is (from the perspective of the Chronicler) the year that epitomises and summarises the deeds of King Josiah. The righteousness of the king (34:2) is best illustrated by his proper celebration of the Passover on "the fourteenth of the first month" of this year (35:1). The main focus of the narrative is therefore the Passover that is described so elaborately in the first nineteen verses of chapter 35 .

ii) Many commentators have referred to the important role that the verb ("to order/prepare") plays in the Josiah narrative ${ }^{21}$. The verb occurs seven times in the narrative, namely in vss. 4, 6, 10, 14(2x), 15,16 . The verb כון resonates in particular in the description of the celebration of the Passover (vss. 10-16). This section is enclosed

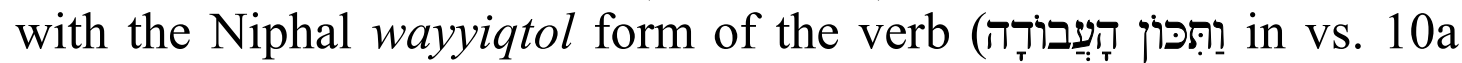

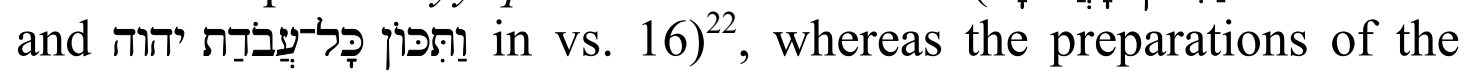
Levites for the other officials is described with the Hiphil (we)- $X$ qatal form of the verb (vss. 14a, 14b, 15b $\beta$ ). The use of the same verb accentuates the obedience of the Levites (vss. 10-16) to the command of the king (vss. 3-6) ${ }^{23}$.

A concordance search shows that 42 of the 108 Hiphil occurrences of the verb כון are in Chronicles ${ }^{24}$. It is quite significant that 28 of the 42 occurrences in Chronicles are used in the temple building narratives of David-Solomon ${ }^{25}$, as well as the Hezekiah ${ }^{26}$ -

21 Cf. e.g. De Vries (1989:414); Japhet (1993:1053); Johnstone (1997: $248 \mathrm{ff}$.).

22 Cf. also Williamson (1982:406): "The same verb is used at v. 16 below to introduce the conclusion of the account. This is therefore strongly suggestive of the Chronicler's own composition".

23 When a next section of the Chronistic Josiah narrative is introduced by a temporal marker in 2 Chron. 35:20, the Hiphil form of the verb כis again used. It seems as if the verb, with sת as object, functions here as a technical term that summarises everything that was told beforehand.

24 According to the Quest II concordance, the verb occurs 216x (all forms) in the Old Testament, of which 50 occur in Chronicles.

251 Chron. 22:3,4[2x],10,14[2x]; 1 Chron. 28:2,7; 1 Chron. 29:2,3,16,18, 19; 2 Chron. 1:4; 2 Chron. 2:6,8; 2 Chron. 3:1

262 Chron. 29:19,36; 2 Chron. 30:19; 2 Chron. 31:1[2x]. 
$\mathrm{Josiah}^{27}$ stories. It seems as if the Niphal form of the verb also plays a structuring role in this context. In 2 Chron. 8:16 it is said that all

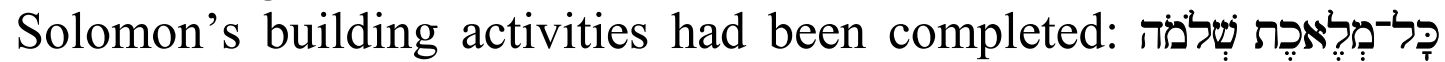
וַת . The next occurrence of the Niphal is in 2 Chron. 29:35 at the

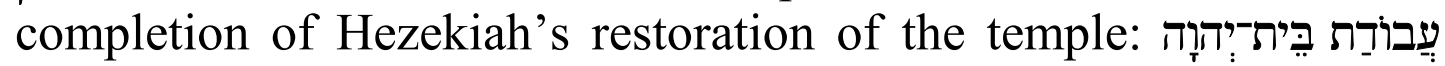

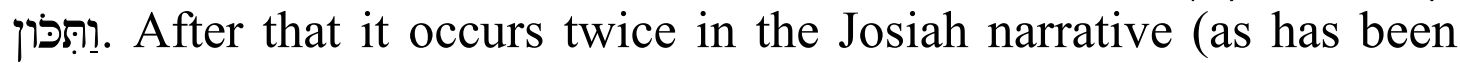
shown above). The completion of the temple (for the first time, and after its restoration), as well as the celebration of the Passover under King Josiah, is linked by means of the Niphal form of the verb כון.

The last overall occurrence of the verb (here in the Hiphil) in Chronicles, is in the first sentence of the concluding section of the Josiah account (2 Chron. 35:20). Not only the temporal marker in this verse and the change in location are significant, but also the

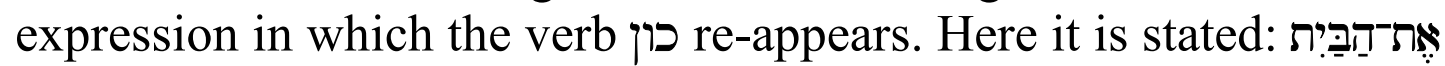

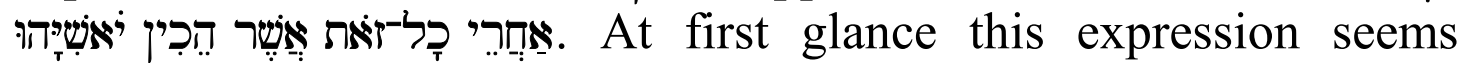
strange, because the actual focus of the Josiah narrative is on the Passover celebrations and not the temple restoration (although that also plays a role in the narrative). However, when this expression is viewed against the background of the wider text-internal contexts and the overall texture of the Books of Chronicles, it seems to be the way in which the Chronicler establishes a closure / "GestaltschlieBung" 28 . What was started under David and Solomon and symbolised and embodied in the building of the temple, was completed in the Passover celebrations during King Josiah's reign. The "house" is now complete ${ }^{29}$ after the proper celebration of the Passover, in which the Levites play a major role.

According to Gerstenberger ${ }^{30}$, this same verb כון (particularly in the Niphal) is used mainly in the Old Testament in contexts where the formation or foundation of e.g. the earth or Mount Zion is

272 Chron. 35:4,6,14[2x],15,20.

28 Cf. Riley (1993:Ch. 2) where 2 Chron. 35:20 is also indicated as a climax in the overall construction of the Chronicler.

29 The word "complete" is explicitly used here as an indication of the meaning of the verb in 2 Chron. 35:20. It is not about "completing" the house that was started under David and Solomon, but about its "completeness". The context of "creation" and "foundation" that is probably also suggested by the verb 2 , is reflected in this choice as well.

30 Cf. Gerstenberger (1971:812-817). 
described. In Psalms, therefore, it occurs mainly in hymns about creation. He also indicates that the root of this verb occurs in many cognate languages (e.g. Ugaritic, Phoenician-Punic, Arabic and Ethiopic), meaning "to be, to happen". Koch ${ }^{31}$ agrees with this view. He states that the cultic use of this lexeme could be explained with reference to the ancient belief that the cult is actually the source of life and prosperity. The cult was seen as being related to the creative acts of Jahweh. By using this verb so prominently in the Josiah Passover account, the Chronicler probably hinted at a universal context as the background for this cultic ritual.

iii) Hezekiah's Passover celebrations are mentioned in 2 Chronicles 30. Certain elements of the Hezekiah Passover narrative, when compared to similar elements in the Josiah account, provide interesting material for our analysis: (a) In the Hezekiah narrative it is stated (cf. 2 Chron. 30:15) that, after some deliberations about the date (cf. 2 Chron. 30:2ff.), the Passover lamb was slaughtered on the fourteenth of the second month. Two main reasons are offered for the postponement of the celebrations: there were not enough consecrated priests to perform the sacrificial duties, and the people were not gathered in Jerusalem yet (2 Chron. 30:3). In the Josiah account, however, the Passover celebrations were held on the fourteenth of the first month. The fourteenth of the first month is stipulated in the Pentateuchal laws (Ex. 12; Num. 9; Deut. 16) as the date on which consecrated people should celebrate the Passover. The fourteenth of the second month is, however, stipulated in Numbers 9 as the date on which unclean and foreign people, as a concession, could still celebrate the Passover. The reason for the different dates in the two Passover accounts in Chronicles should probably be sought on a literary level. The Chronicler's use of the dates is a literary technique designed to build the narrative up to a climax. Hezekiah's Passover prepared the way for the proper celebration of this feast. (b) Both the Hezekiah and Josiah accounts include evaluations. In 2

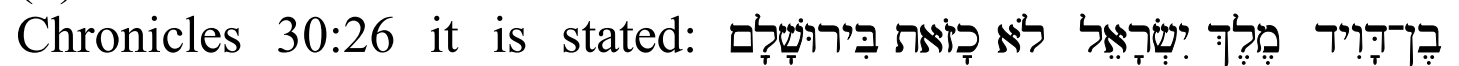

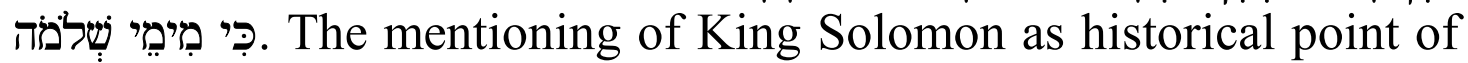
comparison (as will be shown below), is quite significant in this context. The evaluative comment in the Josiah narrative (2 Chron. 35: 18) explicitly states that the Passover has not been celebrated since the days of the prophet Samuel. This reference is problematic within

31 Koch (1984:95-107). 
the overall account, where Hezekiah's Passover is mentioned only a few chapters earlier. The word כמדּה seems to be important here. My argument is that this word does not use the celebration of the Passover as such as a point of comparison ${ }^{32}$. The concern is to compare the quality of the Josiah Passover to those of previous occasions ${ }^{33}$. Such an understanding of this reference would provide additional support for the argument proposed in the discussion above on the different dates of Josiah's and Hezekiah's respective Passover celebrations. The qualitative comparison would present the Josiah Passover as the climax of the building-up process. The comment does not devalue Hezekiah's Passover, but accentuates Josiah's Passover as the proper celebration. Together with some communicative structural indications ${ }^{34}$, Josiah's Passover is presented here as the culmination of a long process of development that started with David and Solomon.

iv) The points mentioned here correspond with the observation documented by many studies ${ }^{35}$, that King Hezekiah is actually portrayed as a second Solomon by the Chronicler. The thread of the texture running from David-Solomon to Josiah is not only established by references in the Josiah narrative itself, but also via the Hezekiah narrative. Thompson, for example, indicates that the expression "the whole assembly" (כל־]ה[קהל) is always (with the exception of two instances ${ }^{36}$ ) used in Chronicles in connection with

32 The resultant translation would then be: "The Passover has not been celebrated in Israel ...".

33 The qualitative comparison could best be represented in translation with "Such a Passover has not been celebrated ....", or "A Passover such as this one has not been celebrated ...".

34 Cf. particularly the discussion below on the role of the verb כון in creating a link with the David-Solomon narratives, as well as the last occurrence of this verb in the Chronicles, in 2 Chronicles 35:20.

35 Cf. e.g. Williamson (1977:119-125 and 1982:371); Dillard (1987:242243); Japhet (1993:956); Thompson (1994:356); Johnstone (1997:206); and Dennerlein (1999:241).

36 In 2 Chron. 23:3 it is used in connection with Joash's coronation, while it is used in 2 Chron. 28:14 (an occurrence omitted by Thompson) within the context of the reign of Ahaz and the Syro-Ephraimitic war. Another occurrence omitted by Thompson, namely 2 Chron. 31:18, also occurs in connection with Hezekiah. 
David, Solomon and Hezekiah. A concordance search on שמחה in Chronicles yields similar results. In 10 of the 12 cases that it occurs in the Books of Chronicles, it is used in connection with David, Solomon and Hezekiah ${ }^{37}$. Many commentators, therefore, argue that the theme of "joy" in Chronicles is not unrelated to the theme of "the whole assembly", and that these related themes are explicitly associated with David, Solomon and Hezekiah (with Josiah related to the last-mentioned $)^{38}$.

iv) These observations may lead us to propose the following macro-structure in the Books of Chronicles:

Temple

DAVID

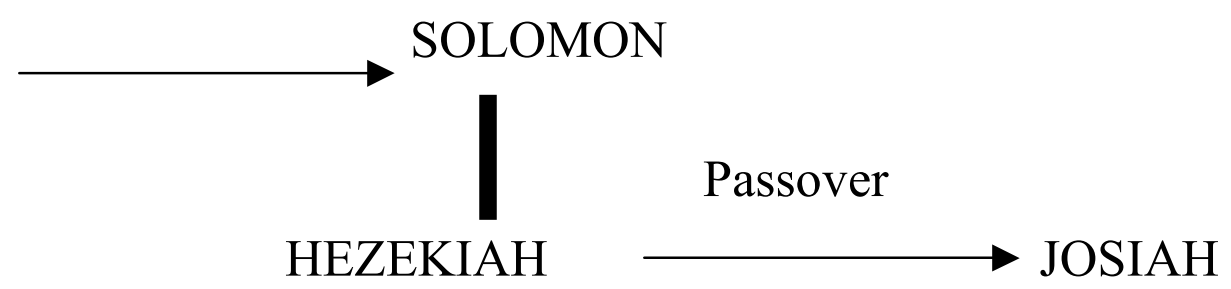

The relationship between David and Solomon is clear: David prepared the temple building process, while his son completed what he intended. The relationship between Hezekiah and Josiah is of a similar kind. The reinstitution of the Passover under Hezekiah was completed and institutionalised under Josiah ${ }^{39}$. The suggestion of the Chronicler's construction is that the development from David to Solomon (that was interrupted by the division of the United Monarchy) was taken up by Hezekiah again, and that it climaxed during the reign of King Josiah ${ }^{40}$.

The description of the Passover within this macro-structure seems to play a pivotal role in the interaction between past and

37 The other two are 2 Chronicles 20:27 (in connection with Jehoshaphat) and 2 Chron. 23:18 (in connection with Joash).

38 Cf. Williamson (1982:371) and Japhet (1993:956).

$39 \mathrm{Cf}$. the motivation of the king's order to the Levites in 2 Chronicles $35: 4$.

40 Cf. Johnstone (1997:206): "The high-water mark of piety that Hezekiah's reign represents is indicated by the comparison with Solomon (v. 26): the occasion and the joy engendered by it are without parallel since Solomon's time. What had been intended at the beginning has now been brought once again to realisation". Johnstone does, however, not acknowledge sufficiently that the narrative development continues in the story of Josiah. 
present in the Chronicler's time. The Chronicler's account differs significantly from the parallel account in the Deuteronomistic History. The Chronicler's account does not only alter the presentation of King Josiah (a shift from idealisation to instrumentalisation), but also introduce an institutionalising and universalising tendency into the narrative. Furthermore, it accentuates the role of the cultic personnel in the description of this institution.

The new situation under Persian rule (without a Davidic king) would have prompted a new reflection on their traditions which presented the Davidic lineage as one of the foundation stones of their being elected by Jahweh. The evaluations of these past kings by their older traditions were not altered. King Josiah is still being thought of as a good king - one of the best they had. However, their rewriting of this king's history within the new context assigned a new function to this king. He is no longer viewed, as was the case in their older tradition, as the one epitomising and legitimising the Deuteronomistic theological tradition. Rather, he now serves the role of accentuating the cultic tradition (the Passover, in particular). It is not kingship that is at stake in the new situation, but the cult. Who they were no longer primarily depended on having a Davidic king, but on the presentation and observance of their cultic traditions. These traditions are then described not in a nationalistic context, but in a universal sphere. The institution of the Passover is not in the first place particularistic, applying to Jahweh's people exclusively in opposition to other nations and their gods. It is rather an institution characteristic of Jahweh's people as part of a wider humanity.

\section{THE RHETORICS OF FINDING A NEW IDENTITY}

It has been argued above that the rhetorics of the Books of Chronicles can be plausibly explained within the field of tension between "continuity" and "new identity" during the late post-exilic era. An analysis of the macro-structure of the books, as well as a comparison to the parallel description of Israelite history in the Deuteronomistic History, provide us with clear indications of the direction of re-interpretation and re-appropriation that took place in the Persian period. These indications help us to grasp the rhetorical function of this literature. As performative literature, its aim was to contribute to the dynamic discourse on finding a new national identity during the time of the Persian province of Jehud. 
The following table provides a summary of the results achieved thus far in my analysis:

\begin{tabular}{|l|l|}
\hline Continuity & New Identity \\
\hline $\begin{array}{l}\text { Attitude towards older traditions: } \\
\text { conservation and further develop- } \\
\text { ment }\end{array}$ & $\begin{array}{l}\text { Attitude towards older traditions: } \\
\text { re-appropriation and exegesis }\end{array}$ \\
\hline Office of orientation: Kingship & $\begin{array}{l}\text { Office of orientation: (Levitical) } \\
\text { Priesthood }\end{array}$ \\
\hline $\begin{array}{l}\text { Societal orientation: Nationa- } \\
\text { listic }\end{array}$ & $\begin{array}{l}\text { Societal orientation: Religious- } \\
\text { cultic }\end{array}$ \\
\hline $\begin{array}{l}\text { Theology: Particularistic (al- } \\
\text { though a universalistic tendency } \\
\text { also occurred in some parts of } \\
\text { society) }\end{array}$ & $\begin{array}{l}\text { Theology: Universalistic (al- } \\
\text { though a particularistic tendency } \\
\text { also occurred in some parts of } \\
\text { society) }\end{array}$ \\
\hline $\begin{array}{l}\text { Institution of orientation: Temple } \\
\text { Institution of orientation: (Writ- } \\
\text { ten) Torah/Passover }\end{array}$ \\
\hline $\begin{array}{l}\text { Orientation of "inward" dis- } \\
\text { course: the past and present }\end{array}$ & $\begin{array}{l}\text { Orientation of "inward" dis- } \\
\text { course: the present and future }\end{array}$ \\
\hline $\begin{array}{l}\text { Intention of "outward" discourse: } \\
\text { opposition and resistance to } \\
\text { present order }\end{array}$ & $\begin{array}{l}\text { Intention of "outward" discourse: } \\
\text { legitimisation of and integration } \\
\text { into present order }\end{array}$ \\
\hline
\end{tabular}

A comment should be made about the distinction used in the table between "inward" and "outward" discourse. I have argued elsewhere $^{41}$ that the textual communication in the Books of Chronicles (as certainly in most communication) is multi-faceted, and should not be understood as being addressed only to the own community within broader society. Probably it had the simultaneous intention of addressing broader society (the Persian leaders, in particular). The discourse directed towards the own community is called "inward" discourse here, while that directed towards broader society is called "outward" discourse.

Another important comment should be made about the power position in society from which this literature originated. If the view

41 Cf. Jonker( 2003). 
is accepted that the Levites, who were not in the centre of power in the late Persian society, were responsible for the origin of the Books of Chronicles, as many scholars argue, it would then seem most probable that the intended audience was not broader society in the first place $^{42}$, but rather those in society that endangered or suppressed the position of the Levites. That means that the discourse in this literature was mainly directed inwards to the religious establishment of the province of Jehud in Jerusalem. The pragmatic function would then be to counter the values of mainstream society, and to argue for (at least) an equal position among the clergy in Jerusalem. Such a description of the rhetorical function of Chronicles would fit plausibly into the text-external context, namely the late Persian society as described above. The openness of this society towards religious diversity could have provided the context in which the Levites found enough moral support to put their case more powerfully. The textinternal contexts of the Chronistic Josiah account support this theory as well. The emphasis on King David (who gave the Levites a new position), the narrative line from David to Solomon, and again from Hezekiah to Josiah, the association with temple building and Passover celebration all support a strategy of bolstering and advocating the position of the Levites.

\section{THE SOUTH AFRICAN CONTEXT? SOME OBSERVA- TIONS}

It would be dangerous and inaccurate to make any generalised conclusions from this analysis for all religious communities in the postapartheid South Africa. The different religious communities, even the different communities within the Christian religion, are situated differently in the South African society, and they have different experiences of the socio-political and accompanying changes that have taken place since 1990. The analysis of the rhetorics of finding a new identity in the Persian province of Jehud, can therefore not be forced onto present-day South African society.

However, some of the features analysed above can also be observed in certain Christian communities. Without trying to systematise, and being aware of the danger of generalisation, I want to

42 It could, however, also have been possible that broader society might be intended as a "secondary" audience, i.e. as those who should also hear about this strife in order to support the argument advanced in the text. 
express a few observations about the Christian community to which I belong, namely the Dutch Reformed Church (DRC):

i) Both the categories of "continuity" and "new identity" could be used to describe the present situation in the DRC. The diverse population of this church did not and still does not react homogeneously to the socio-political changes in the country. It could be argued that the rhetorics in some parts of this church (or, by a percentage of the membership) are characterised by what was called in the above analysis a tendency towards continuity. They have a conservationist approach to Scripture, they orientate themselves in society according to social-religious conventions of the past, and they react with resistance towards the development of a secular society in South Africa. In other parts of the membership a search towards a new identity could be detected. These members search to re-appropriate Scripture for their present circumstances, they orient themselves towards the future, and they attempt to integrate into the secular (multi-ethnic and multi-religious) society of South Africa.

ii) Although adherents to both the categories of "continuity" and "new identity" were always present in the DRC, a shift in power relations has taken place during the past few year. In the pre-1990 (perhaps pre-1986) era, those who advocated continuity were in the majority, not only quantitatively, but also with regard to the power structures in the church. Those advocating a new identity remained in a minority position. The socio-political and socio-cultural transformation of the past ten to fifteen years in this country has amplified the voice of the minority position. Although it is difficult to tell whether the power relations in the church have changed, it is clear that the rhetorics of finding a new identity have become louder and more visible in the past decade.

iii) Another observation is the change from a strong tendency towards outward discourse in the past, to a tendency towards inward discourse at present. Whereas the DRC was very visible and audible during the previous socio-political era, commenting on and even influencing legislation on ethical and socio-political issues, the outward voice of this church has become silent during the past decade. A fairly big part of the membership for whom outward discourse is part of this church's identity, is accusing the church leadership at present of not speaking out on socio-political and especially ethical issues. My observation is, however, that the voice of the church has not become silent, but that the direction of discourse has changed. 
Almost all meetings of the church leadership at different levels, as well as of the membership, in some or other way grapple with the questions: Who are we in the New South Africa, and how should we position ourselves, taking into account our sad history during the Apartheid years? Much energy is dedicated to this process of inward discourse.

iv) The inward discourse takes on different forms. To my mind, present debates on the authority and interpretation of Scripture, about a so-called New Reformation, on ethical and pastoral issues such as homosexuality, and on the topic of interreligious dialogue, are all expressions of the multi-faceted inward discourse facilitating the transition from a strong tendency towards continuity to the search for a new identity.

v) The identity of the DRC during the phase of continuity in the Apartheid years was closely associated with and related to the sociopolitical power centre. One of the characteristics of this era was that the DRC leadership had far better relationships with political leaders than with leaders from other Christian denominations and other religions. The ecumenical self-isolation of these years expressed this tendency clearly. However, in the past few years the DRC leadership, on different levels, have dedicated themselves strongly towards the cultivation of ecumenical relationships, and even interreligious dialogue. To my mind, this change should not merely be viewed as pragmatic and strategic. It is also an indication that a shift is taking place within the DR Church from an identity defined in sociopolitical terms, to a socio-religious identity.

vi) My last observation is related to the previous one. In the preNew South African era, the DRC had a strong institutional role in society and among its membership. The church as institution, strongly bolstered by a powerful leadership, a detailed church order and a judicial interpretation of the confessions, represented the membership in society, and defined their social and ethical boundaries. Although at least a part of the present-day membership still long for the institutional role of the DRC, this view of the church has come under pressure within the church itself. A strong tendency towards ritualisation seems to have substituted the tendency towards institutionalisation. A growing percentage of the church membership expresses their need of a ritualising of reality, instead of the need for institutionalised security. 


\section{CONCLUSION}

Bearing in mind that the above observations are very subjective and personal, and are not supported in any way by empirical research, they illustrate how the study of the rhetorics of finding a new identity in the Books of Chronicles can sensitise present-day faith communities to the very complicated dynamics of finding a new identity in the present period of socio-cultural and socio-political change in South Africa.

\section{Consulted literature}

Carter, C E 1999. The Emergence of Yehud in the Persian Period: A social and demographic study. Sheffield: Sheffield Academic Press (JSOT Sup 294).

Davies, P R (ed.) 1991. Second Temple Studies 1: Persian Period. Sheffield: Sheffield Academic Press (JSOT Sup 117).

Deist, F E 2000. The material culture of the Bible. An introduction. Sheffield: Sheffield Academic Press.

De Vries, S J 1989. 1 and 2 Chronicles. Grand Rapids, M: Eerdmans.

Dennerlein, N 1999. Die Bedeutung Jerusalems in den Chronikbüchern. Frankfurt: Peter Lang.

Dillard, R B 1987. 2 Chronicles. Waco, Texas: Word Books.

Donner, H 1986. Geschichte des Volkes Israel und seiner Nachbarn in Grundzügen 2, Göttingen: Vandenhoeck \& Ruprecht.

Gerstenberger, E 1971. "kun”, THAT I, 812-817.

Japhet, S 1993. I and II Chronicles. London: SCM Press.

Johnstone, W 1997. 1 and 2 Chronicles. Vol. 2. Sheffield: Sheffield Academic Press.

Jonker, L C 2003a. Josiah in the Chronicler's mirror. Late stages of the Josiah reception in II Chr 34f. Gütersloh: Gütersloher Verlag.

-, 2003b. "Completing the temple with the celebration of Josiah's Passover?", Old Testament Essays 15/2, 381-397.

Klein, R W 1992. "Chronicles, Book of 1-2" in Anchor Bible Dictionary Vol. 1, 992-1002.

Koch, K 1984. "כון", TWAT IV, 95-107.

Porten, B \& Yardeni, A 1986. Textbook of Aramaic documents from Ancient Egypt. Jerusalem: Hebrew University.

Porten, B (ed.) 1996. The Elephantine papyri in English: Three millennia of cross cultural continuity and change. Leiden: Brill.

Roubos K 1983. II Kronieken. Nijkerk: Callenbach. 
Riley, W 1993. King and cultus in Chronicles. Worship and the reinterpretation of history. Sheffield: JSOT Press.

Strübind, K 1991. Tradition als Interpretation in der Chronik. König Josaphat als Paradigma chronistischer Hermeneutik und Theologie. Berlin: De Gruyter.

Thompson, J A 1994. 1, 2 Chronicles. S.1.: Broadman \& Homan Publishers.

Willi, T 1972. Die Chronik als Auslegung. Untersuchungen zur literarischen Gestaltung der historischen Überlieferung Israels. Göttingen: Vandenhoeck $\&$ Ruprecht.

-, 1995. Juda - Jehud - Israel. Studien zum Selbstverständnis des Judentums in persischer Zeit. Tübingen: Mohr (Siebeck), (FAT 12).

-, 1999. Leviten, Priester und Kult in vorhellenistischer Zeit. Die chronistische Optik in ihrem geschichtlichem Kontext, in Ego, B., Lange, A., Pilhofer, P Gemeinde ohne Tempel. Zur Substituierung und Transformation des Jerusalemer Tempels und seines Kults im Alten Testament, antiken Judentum und frühen Christentum. Tübingen: Mohr Siebeck.

Williamson, H G M 1977. Israel in the Books of Chronicles. Cambridge: Cambridge University Press.

-, 19821 and 2 Chronicles. Grand Rapids: Eerdmans (NCBC). 